\title{
Photonic crystal fibers: fundamentals to emerging applications
}

\section{Bjarklev, Anders Overgaard}

\section{Published in:}

Conference on Lasers and Electro-Optics, 2005. (CLEO).

Publication date:

2005

Document Version

Publisher's PDF, also known as Version of record

Link back to DTU Orbit

Citation (APA):

Bjarklev, A. O. (2005). Photonic crystal fibers: fundamentals to emerging applications. In Conference on Lasers and Electro-Optics, 2005. (CLEO). IEEE.

\section{General rights}

Copyright and moral rights for the publications made accessible in the public portal are retained by the authors and/or other copyright owners and it is a condition of accessing publications that users recognise and abide by the legal requirements associated with these rights.

- Users may download and print one copy of any publication from the public portal for the purpose of private study or research.

- You may not further distribute the material or use it for any profit-making activity or commercial gain

- You may freely distribute the URL identifying the publication in the public portal

If you believe that this document breaches copyright please contact us providing details, and we will remove access to the work immediately and investigate your claim. 


\title{
Photonic Crystal Fibers: Fundamentals to Emerging Applications
}

\author{
Anders Bjarklev \\ Research Center COM, Technical University of Denmark, DTU Building 345v, Oersteds Plads, DK-2800 Kgs.Lyngby, Denmark. \\ E-mail: ab@com.dtu.dk
}

\begin{abstract}
A review of the fundamental properties of photonic crystal fibers is presented. Special focus is held on the emerging fields of application within areas such as actively controlled fiber devices and high-power fiber lasers.

$\square 2005$ Optical Society of America

OCIS codes: (060.2330) Fiber optics communications; (060.2310) Fiber optics
\end{abstract}

\section{Summary}

Microstructured optical fibers (or Photonic Crystal Fibers, PCF's) have over the past 8 years attracted a strong research interest within the field of modern optical waveguides. During this period, many new and exciting microstructures have been proposed and many of the most interesting have been realized in the research laboratories or by the emerging industry.

The research have gone through a very interesting development from the point, where the initial activities on fiber manufacturing considered the ideas of having thin strands of glass surrounded by air over the introduction of the first photonic bandgap structures in the late 1980'ies. With the early work on photonic crystal structures in optical fibers, a new generation of fiber waveguides was born, and a search for the optimal structures for hollow waveguides was initiated. During the past couple of years many interesting and also surprising results have been found and presented to the international research community, and the area of photonic crystal fibers include today both fibers operating by the photonic bandgap effect and those using the more conventionally accepted principle of modified total internal reflection.

The research field has, however, first now reached a level of maturity, where fiber attenuation is getting close to that of standard optical fibers, and where a high level of production reproducibility has been obtained.

Most of the work on photonic crystal fibers has been done with reference in the silica glass base material, but also other possibilities exist, e.g., low-melting-point glasses or polymers, which allows for alternative fabrication methods and also the realization of novel fiber properties including much higher nonlinear coefficients etc. The literature on the subject of photonic crystal fibers is consequently full of new ideas and exiting applications, but most importantly, the field is getting more mature.

Therefore, we are at the threshold of a development, where microstructured fibers will move from research laboratories and into actual production of optical devices and systems. In this process, it is likely that microstructured double-clad fibre lasers and nonlinear signal processing devices will be among the first to reach the market, whereas many other exciting possibilities within areas such as actively controlled PCF's or gas- or liquid-filled devices also emerge. In this presentation, a review of the most interesting microstructured fiber classes will be given and future development perspectives will be addressed. 